日本臨床麻酔学会第 38 回大会シンポジウム 日臨麻会誌 Vol.39 No.4, 416 422, 2019

臨床研究法にどう対応するか

臨床研究法の概要

桑原宏哉

[要旨] 臨床研究で生じたデータの操作や利益相反行為という不正事案を受け, 臨床研究法が 2018年4月 1 日に施行された. 臨床研究を推進することと規制することのバランスを考慮し, 臨床研究法は, 臨床研究の実施に係る行動主体(当局, 臨床研究を実施する者, 認定臨床研究審査 委員会, 医薬品等製造販売業者など)及び行動主体間の関係について最低限のルールを定め, 臨床 研究の手続きの明確化と質の充実を図ったものである. 今後も引き続き, 信頼性の高い臨床研究が 実施される環境整備を進めていきたい.

キーワード : 臨床研究法, 特定臨床研究, 認定臨床研究審査委員会, 利益相反, 臨床研究データベ ース

\section{I 臨床研究法制定の背景}

平成 24(2012) 年, 臨床研究の信頼性を損ねる様々 な不正事案が明らかとなった。例えば，高血圧症治 療薬ディオバンの臨床研究におけるデータ操作や利 益相反行為, 高血圧症治療薬ブロプレスの臨床研究 (CASE-J) における処方薬の誇大広告の問題等は, マスコミにも大きく報道された。前者の事案では, 研究データが人為的に操作され, 事実と異なる結論 が導き出されていたこと, ノバルティスファーマ株 式会社の元社員がこれらの臨床研究の統計解析作業 業務へ関与していたこと等が明らかになった。

これを受けて, 当該事案の状況把握と対応の検討 を行い, 再発を防止するため, 平成 25 (2013) 年 8 月, 厚生労㗢大臣の下に「高血圧症治療薬の臨床研究事 案に関する検討委員会」が設置された。本検討会に おいて，関係者に対するヒアリングや関係資料の精

*厚生労働省医政局研究開発振興課
査を含めた調査等が行われ，平成 26(2014) 年 4 月に 「高血圧症治療薬の臨床研究事案を踏まえた対応及 び再発防止策について(報告書)」が取りまとめられ た ${ }^{1)}$.

これまで,わが国で行われる臨床研究については, 法規制は存在しておらず，「臨床研究に関する倫理 指針」(平成 15 年厚生労働省告示第 255 号。以下「倫 理指針」という.）に基づいて実施されてきた。倫理 指針においては，被験者に対するインフォームド・ コンセントの実施，個人情報保護等の研究者の責務 や，倫理審査委員会での審査等に関する事項が定め られていたが，指針を遵守できていない場合であっ ても行政指導に法的拘束力はなかった。このような 状況を踏まえ，上記の報告書は，研究不正の再発防 止策として，倫理指針の見直しの一環として必要な 対応を図るべき旨及び法制度の必要性について検討 をするべき旨を示した。 


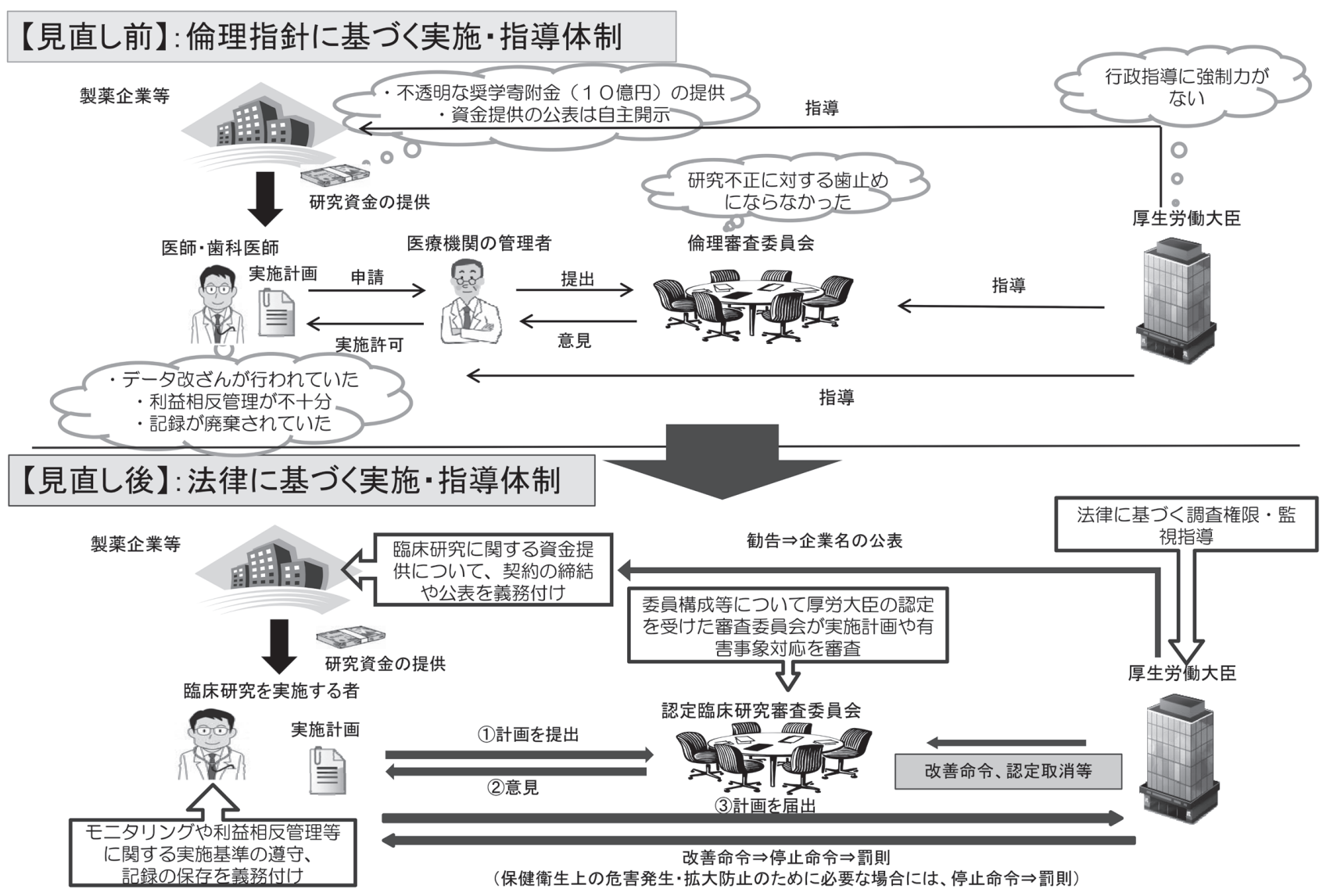

図1 法制度による見直しの考え方

厚生労働省は,「臨床研究に係る制度の在り方に 関する検討会」を平成 26 年 4 月に立ち上げ，同年 11月までの間，多くの関係者からのヒアリングを 行うなどして検討を行った。本検討会は，同年 12 月に「臨床研究に係る制度の在り方に関する報告書」 を取りまとめ, その中で, 臨床研究の質を確保し, 臨床研究に関する信頼を回復するためには, 現行の 倫理指針の遵守だけでは十分とは言えないこと，一 方で，法規制によって研究の萎縮を招かないように しなければならないことを指摘し, 一定の範囲の臨 床研究について法規制が必要であると結論付けた ${ }^{2)}$. 倫理指針は，平成 26 年 12 月，「疫学研究に関す る倫理指針」(平成 14 年文部科学省・厚生労働省告 示第 2 号) と統合するとともに，利益相反に関する 規定・モニタリング・監査や資料の保存に関する規
定等を新たに設け，「人を対象とする医学系研究に 関する倫理指針」(平成 26 年文部科学省・厚生労働 省告示第 3 号. 以下「医学系指針」という.)が公布 され，平成 $27(2015)$ 年 4 月 1 日に施行された ${ }^{3)}$.

臨床研究法は, 上記の報告書において示された「法 規制の範囲」や「具体的な規制や対策の内容」等を 踏まえて起草され, 国会での審議を経て, 平成 29 (2017) 年 4 月に成立・公布，平成 30 (2018) 年 4 月 1 日に施行された ${ }^{4)}$ 。また，臨床研究法施行規則 (平 成 30 年厚生労働省令第 17 号. 以下「規則」という。) については, 平成 29 年 8 月より, 厚生科学審議会 臨床研究部会において議論が行われ，パブリックコ メントを経て同部会へ諮問答申の後，平成 30 年 2 月末日に公布され，同年4月1日に施行された ${ }^{5)}$ (図1). 


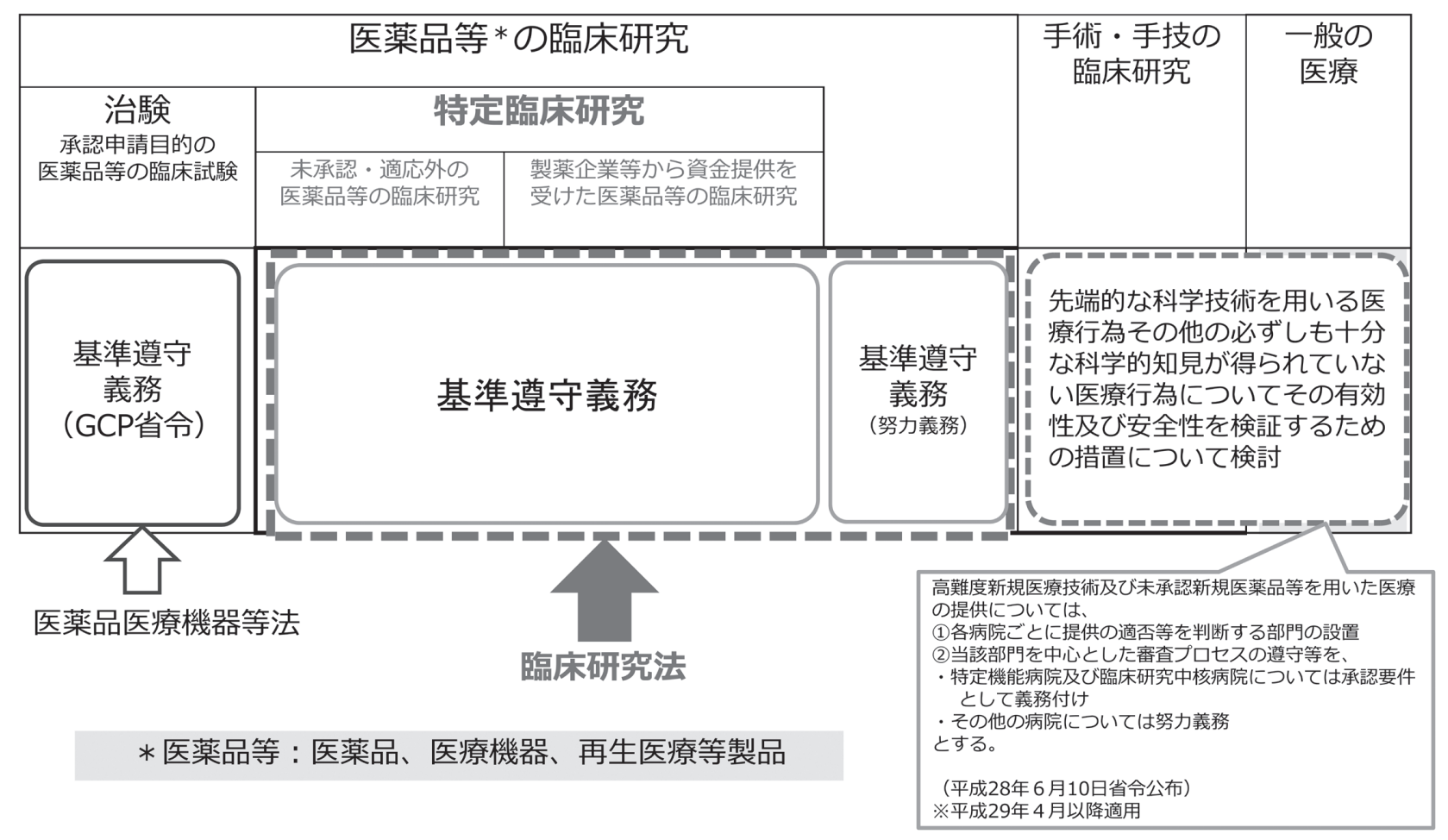

図2 医療における規制の区分

\section{II 臨床研究法の概要}

臨床研究法は, 臨床研究の実施の手続, 認定臨床 研究審査委員会による審査意見業務の適切な実施の ための措置，臨床研究に関する資金等の提供に関す る情報の公表の制度等を定めることにより, 臨床研 究の対象者をはじめとする国民の臨床研究に対する 信頼の確保を図ることを通じてその実施を推進し, もって保健衛生の向上に寄与することを目的とした ものである。

\section{1. 法第 1 章 総則(法第 1 条一第 2 条, 規則第 1 条一第 7 条)}

1) 臨床研究法における臨床研究 (図2)

臨床研究法の対象となる臨床研究は, 「医薬品等 を人に対して用いることにより, 当該医薬品等の有 効性又は安全性を明らかにする研究」と定義されて いる。ここでいう「医薬品等を人に対して用いる」 とは, 医薬品等(医薬品, 医療機器又は再生医療等 製品をいう。以下同じ.)を人に対して投与又は使用
する行為のうち，医行為に該当するものを行うこと をいう。なお，医行為とは，「医師法第 17 条，歯科 医師法第 17 条及び保健師助産師看護師法第 31 条の 解釈について (通知)」(平成 17 年 7 月 26 日付け医政 発第0726005号厚生労㗢省医政局長通知）における 医行為をいう。

2)臨床研究法に該当しない臨床研究

以下のものは臨床研究法における臨床研究に該当 しない.

-手術・手技の臨床研究

・研究の目的で検査, 投薬その他の診断又は治療の ための医療行為の有無及び程度を制御することな く, 患者のために最も適切な医療を提供した結果 としての診療情報又は試料を利用する研究(いわ ゆる「観察研究」)

・治験

- 医薬品，医療機器，再生医療等製品の製造販売後 調査等であって, 再審査, 再評価, 使用成績評価 
に係るもの

・医療機器の認証に係る基準適合性に関する情報の 収集のために行う試験

・体外診断用医薬品に係る臨床研究

3)特定臨床研究

臨床研究のうち，以下のいずれかに該当するもの を「特定臨床研究」と定義し, 臨床研究法の基準遵 守義務を課している.

-「医薬品, 医療機器等の品質, 有効性及び安全性 の確保等に関する法律」(昭和 35 年法律第 145 号) に基づく承認・認証・届出の無い医薬品等を用い て，その有効性又は安全性を明らかにする臨床研 究

・適応外の用法・用量等で医薬品等を用いて，その 有効性又は安全性を明らかにする臨床研究

・当該臨床研究における医薬品等製造販売業者また はその特殊関係者 (子会社等)から資金の提供を受 けて実施される臨床研究

4)特定臨床研究以外の臨床研究

臨床研究法における臨床研究のうち, 特定臨床研 究以外の臨床研究は, 臨床研究法の基準遵守におい て努力義務が課せられている.

2. 法第2 章 臨床研究の実施 (法第3条一第22条, 規則 第8条一第63条)

1) 臨床研究法の基本理念

臨床研究法における臨床研究の基本理念を以下の 通りに定めている。これは, 人を対象とする臨床研 究の長い歴史的な経緯を踏まえ, 臨床研究の対象と なる者の人権の尊重に関する国内外のガイドライン 等の諸原則を整理し, 臨床研究のプロセスに応じて 示したものである。

・社会的及び学術的意義を有する臨床研究を実施す ること

・臨床研究の分野の特性に応じた科学的合理性を確 保すること

- 臨床研究により得られる利益及び臨床研究の対象 者への負担その他の不利益を比較考量すること
・独立した公正な立場における審査意見業務を行う 認定臨床研究審査委員会の審査を受けていること ・臨床研究の対象者への事前の十分な説明を行うと ともに，自由な意思に基づく同意を得ること

・社会的に特別な配慮を必要とする者について，必 要かつ適切な措置を講ずること

・臨床研究に利用する個人情報を適正に管理するこ と

・臨床研究の質及び透明性を確保すること

2) 臨床研究実施基準

臨床研究法における臨床研究の実施の基準とその 手続きを定めており，特定臨床研究を実施する者に はこれに従う義務が，それ以外の臨床研究を行う者 にはこれに従う努力義務が課せられている。主な内 容は以下の通りである。

・研究責任医師等の責務等

・実施医療機関の管理者等の責務

・多施設共同研究

・疾病等発生時の対応等

・認定臨床研究審査委員会への疾病等の報告

・厚生労働大臣への疾病等の報告

・研究計画書

・実施計画の厚生労働大臣への提出

・実施計画の変更の届出

・特定臨床研究の中止の届出

・不適合の管理

・実施医療機関の構造設備等

・モニタリング

・監査

・研究対象に対する補償

・利益相反管理計画の作成等

・認定臨床研究審査委員会の意見への対応

・苦情及び問い合わせへの対応

・臨床研究の情報公開等

・臨床研究に用いる医薬品等の品質の確保等

・個人情報の取り扱い

・特定臨床研究の対象者等に対する説明及び同意事 
項

- 特定臨床研究の対象者等の同意の取得

・特定臨床研究に関する記録の保存

- 認定臨床研究審査委員会への定期報告

- 厚生労㗢大臣への定期報告

・秘密保持義務

・特定臨床研究以外の臨床研究を実施する場合に講 ずべき措置

\section{3. 法第3 章 認定臨床研究審査委員会 (法第 23 条一第 31}

\section{条，規則第 64 条一第 87 条)}

臨床研究に関する専門的な知識経験を有する者に より構成され，厚生労㗢大臣の認定を受けた委員会 であって，臨床研究法に掲げる様々な要件に適合し ていることについて審査意見業務を行う。これまで 多施設共同研究の場合には各実施医療機関の倫理審 査委員会の承認を得ていたが，臨床研究法において は全施設分を単一の認定臨床研究審査委員会で審査 し承認を得るようになった(いわゆる中央審査化)こ とが，特徴の一つとして挙げられる。

1) 主な認定要件内容

・設置できる団体

・委員の構成

・審査意見業務を適正に実施する体制

・審査意見業務の適切な実施のための基準

・業務規程で定める事項

・臨床研究審査委員会の認定の申請手続き

2)主な審査意見業務

- 実施計画の新規申請や変更申請の際に, 臨床研究 実施基準に照らして審査を行い, 特定臨床研究の 実施の適否及び実施に当たって留意すべき事項に ついて意見を述べる業務。

・疾病等報告を受けた際に, 疾病等の原因の究明又 は再発防止のために講ずべき措置について意見を 述べる業務。

・定期報告を受けた際に，当該報告に係る特定臨床 研究の実施に当たって留意すべき事項又は改善す べき事項について意見を述べる業務。
・その他必要があると認めるときに，当該特定臨床 研究を臨床研究実施基準に適合させるために改善 すべき事項又は疾病等の発生防止のために講ずべ き措置について意見を述べる業務。

3)特定臨床研究以外の臨床研究の審査 研究責任 (代表)医師から, 臨床研究の実施に関す る計画に係る意見を求められた場合は，特定臨床研 究と同様の業務を行うよう努めなければならない.

4) その他

認定臨床研究審査委員会の委員等には守秘義務が 課せられ，設置者には記録の保存や，委員等に対す る教育又は研修, 認定臨床研究審査委員会の審査手 数料, 開催日程及び受付状況の公表等が求められる.

\section{4. 法第 4 章 臨床研究に関する資金等の提供 (法第 32 条}

一第 34 条，規則第 88 条一第 91 条)

医薬品等製造販売業者又はその特殊関係者(子会 社等) は，当該医薬品等を用いた特定臨床研究を実 施する場合，契約の締結，資金等の提供に関する情 報等の公表が義務付けられた。

1)契約の締結

医薬品等製造販売業者又はその特殊関係者(子会 社等をいう。以下同じ.)は，特定臨床研究を実施す る者に対し, 当該医薬品等製造販売業者が製造販売 をし，又はしょうとする医薬品等を用いる特定臨床 研究についての研究資金の提供を行うときには，研 究資金等の額及び内容等について, 契約を締結しな くてはならない.

2) 情報の公表

医薬品等製造販売業者又はその特殊関係者は，当 該医薬品等製造販売業者が製造販売をし，又はしよ うとする医薬品等を用いる特定臨床研究に関して, 金銭その他の利益の提供に関する情報をインターネ ットにより公表しなければならない.

5. 法第 5 章 雑則 (法第35条一第 38 条, 規則第 92 条一 第 96 条)

1) 報告徵取及び立入検査

厚生労働大臣は，この法律の施行に必要な限度に 
おいて, 特定臨床研究を実施する者, 認定臨床研究 審査委員会の設置者若しくは医薬品等製造販売業者 若しくはその特殊関係者に対して，必要な報告若し くは帳簿, 書類その他の物件の提出を求めることや, 事業場への立ち入りができる。

2) 命令・勧告

厚生労働大臣は，特定臨床研究を実施する者に対 し, 当該特定臨床研究の実施の停止や応急措置をと るべき緊急命令や，違反を是正するために必要な措 置を講ずる改善命令を命ずることができる。また， 認定臨床研究審査委員会の設置者に対し, 要件の不 適合や不適切な審査意見業務が行われた場合, 改善 命令や認定の取消しをすることができる。医薬品等 製造販売業者等に対しては, 契約の締結や情報公開 において規定に従うよう勧告することができ，それ に従わない場合はその旨を公表することができる.

3) 厚生労㗢大臣の権限の委任

この法律に規定する厚生労㗢大臣の権限は, 厚生 労働省令で定めるところにより, 地方厚生局に委任 することができると定めており，この権限の委任に よって, 実施計画の提出や臨床研究審査委員会の認 定の申請等は, 地方厚生局へ提出する運用となって いる.

\section{6. 法第 6 章 罰則 (法第 39 条一第 43 条)}

臨床研究法に基づく命令に違反した者等に対して は，罰金などの罰則が設けられている.

\section{III 臨床研究データベース (jRCT ; Japan Registry of Clinical Trials)}

これまで日本の臨床研究は, UMIN 臨床試験登録 システム (UMIN-CTR), 日本医薬情報センター (JAPIC)，日本医師会治験促進センター(JMACCT) の3機関のいずれかに登録され公表されてきた。臨 床研究法に該当する臨床研究においては, 厚生労働 省が整備するデータベースである $\mathrm{jRCT}$ に登録し， 臨床研究に関する情報とその結果を公表しなければ ならないと定めている ${ }^{6)}$ 。これは, 臨床研究の実施
にあたり世界保健機関 (WHO ; World Health Organization) の国際臨床試験登録プラットフォーム (ICTRP ; International Clinical Trials Registry Platform)が求める事項と, その他の臨床研究の過 程の透明性の確保および国民の臨床研究への参加の 選択に資する事項を登録し公表するものである7.

また，jRCTは，臨床研究の情報公開以外に，認 定臨床研究審査委員会の情報公開としても利用でき るようになっている.

\section{おわりに}

臨床研究法は，臨床研究を実施するにあたり必要 な手続きを法律に定めたものであり，臨床研究の関 係者にはその内容についてご理解の上，適切な臨床 研究の実施に向けた対応をお願いしたい。また，臨 床研究法においては，認定臨床研究審査委員会によ る中央審査化，利益相反管理基準に基づく利益相反 管理の明確化，公的データベースによる臨床研究の 実施に関する情報の一元管理化を行うための仕組み が規定された。本法が遵守されることにより，研究 の透明性や研究の対象者の保護が確保された適正で 効率的な臨床研究が実施されることを期待する。な お, 本稿は臨床研究法の概要を執筆したものであり, 臨床研究を実施する際には臨床研究法, 各種関連法 令・通知等を遵守されたい.

\section{参考文献}

1）厚生労働省 高血圧症治療薬の臨床研究事案に関する 検討委員会 (2014)：高血圧症治療薬の臨床研究事案を 踏まえた対応及び再発防止策について(報告書). $\langle$ http://www.mhlw.go.jp/file/05-Shingikai10801000-Iseikyoku-Soumuka/0000043426.pdf〉

2）厚生労働省 臨床研究に係る制度の在り方に関する検 討会 (2014)：臨床研究に係る制度の在り方に関する報 告書. 〈http://www.mhlw.go.jp/file/05-Shingikai10801000-Iseikyoku-Soumuka/0000068409.pdf〉

3）厚生労働省ホームページ 研究に関する指針について 〈https://www.mhlw.go.jp/stf/seisakunitsuite/bunya/ hokabunya/kenkyujigyou/i-kenkyu/index.html〉

4）厚生労働省ホームページ臨床研究法について 
〈https://www.mhlw.go.jp/stf/seisakunitsuite/bunya/ 0000163417.html〉

5）厚生労働省ホームページ 厚生科学審議会(臨床研究部会) 〈https://www.mhlw.go.jp/stf/shingi/shingikousei_467561.html〉
6）臨床研究実施計画・研究概要公開システム $(\mathrm{jRCT})$ ホー ムページ〈https://jrct.niph.go.jp/〉

7) WHOホームページ International Clinical Trials Registry Platform (ICTRP)〈https://www.who.int/ictrp/ en $/\rangle$

\title{
Overview of Clinical Trials Act
}

\author{
Hiroya KUWAHARA
}

Research and Development Division, Health Policy Bureau, Ministry of Health, Labour and Welfare

The Clinical Trials Act was implemented on April 1, 2018 in response to cases of data manipulation and conflicts of interest in clinical research. While maintaining a balance between promoting and regulating clinical research, the Clinical Trials Act sets minimum rules on the relationships among actors (authorities, clinical researchers, certified review boards, pharmaceutical dealers etc.) and clarifies procedures for clinical research to improve its quality. We would like to continue to improve the environment for clinical research to ensure its reliability.

Key Words : Clinical Trials Act, Specified clinical trial, Certified review board, Conflict of interest, Japan Registry of Clinical Trials

The Journal of Japan Society for Clinical Anesthesia Vol.39 No.4, 2019 